\title{
Are Haematophagous Insects Vectors for HTLV-I?
}

\author{
M.F. Greaves ${ }^{1}$ and G. J. Miller ${ }^{2}$
}

\section{A. Introduction}

Human T-lymphotropic virus I (HTLV-I) and its associated malignancy, adult $\mathrm{T}$-cell leukaemia $[19,30,31,37]$ are endemic in southern Japan [18, 26], the Caribbean Basin and neighbouring mainland America [1, 6, $10,14,23]$, and sub-Saharan Africa [5, 20, 38].

The natural history and mode of transmission of HTLV-I infection is largely unknown. Worldwide, the infection as indicated by the presence of antibodies is confined mostly to tropical areas of high humidity in Japan [36], the Caribbean and tropical South America [7, 23], and Central Africa [4, 5, 20,38]. Sero-positivity for HTLV-I and the associated risk of adult T-cell leukaemia/ lymphoma has been reported among immigrants to temperate regions from the Caribbean $[10,15]$. More recently, southern Italy [22] and the Arctic regions [32] have been identified as possibly additional endemic regions. In the Caribbean, sero-positivity has been found almost entirely in people of African or part-African descent, although there are recent reports of HTLV-I-positive adults among Amerindians in Cayenne [11] and Venezuela [23] and Campuchian immigrants to Cayenne [11].

Earlier studies, especially in Japan, have suggested that HTLV-I might be transmitted by sexual contact [36], from mother to

\footnotetext{
${ }^{1}$ Leukaemia Research Fund Centre, The Institute of Cancer Research, London SW3 6JB, England

${ }^{2}$ Dept. of Epidemiology and Social Medicine, Albert Einstein College of Medicine, New York, NY, USA
}

child via transplacental passage [21] or breast feeding [28], by blood transfusion [16], or by insect vectors [35]. Sexual transmission has been emphasised as a possible major route, but it cannot easily explain the demographic distribution of sero-positivity or the relatively high incidence of HTLV-I antibodies in children whose parents are sero-positive [17]. Neither does it adequately explain why the highest rates of sero-positivity should be observed in 70-year-old Japanese women.

\section{B. A Role for Haematophagous Insects?}

The possibility has been raised that Africans represent the natural host of HTLV-I, and that the virus was introduced in this way to the West Indies and perhaps also to Japan $[13,20]$. In Britain, HTLV-I sero-positivity is found in first generation but very rarely in second generation West Indian people of African descent (Table 1) [15] (M.F. Greaves, T.A. Lister, S. Pegram and L. Chan, unpublished observations). Thus, the circumstances required for transmission may be largely confined to tropical and subtropical areas of high humidity, and - strikingly - to some Arctic regions [32]. Within endemic areas strong associations exist between sero-positivity to HTLV-I and evidence of exposure to arthropod-transmitted diseases such as filariasis [35], malaria [3] and equine encephalitis [23]. These relations might imply human transmission of HTLVI by mosquitoes, shared environmental factors which promote the transmission of HTLV-I and arthropod-borne disease, or 
Table 1. HTLV-I antibodies in United Kingdom residents of Caribbean origin

1. Relatives of HTLV-I ${ }^{+}$adult $\mathrm{T}$-cell leukaemia patients:

23 Relatives of 6 patients

Sero-positive: 0/12 UK born (of Afro-

Caribbean parentage)

4/11 Caribbean born

2. Non-leukaemic serum donors (unrelated to ATL patients):

Series 1: Hospital out-patients

Sero-positive: 6/70 - all positives were born in Caribbean [15]

Series 2: Hospital out-patients + normals Sero-positive: 0/70 UK born (of AfroCaribbean parentage) 6/130 Caribbean born

potentiation of the response to one infection by previous exposure to the other [3].

Involvement of mosquitoes or other haematophagous insects in the transmission of HTLV-I would go some way towards explaining the endemicity of this virus in Arctic regions where such insects are exceedingly common. Recent collaborative studies we have conducted on the Caribbean island of Trinidad provide, we believe, further support for the idea that insects might be vectors for HTLV-1 [25]. Between 1977 and 1981 , blood samples were obtained for a cardiovascular survey of all adults aged 35-69 years and resident within a geographically defined area of Port-of-Spain, Trinidad [24]. In most respondents, sufficient serum had been stored for screening of the community for evidence of HTLV-I infection. As far as we are aware, this is the first systematic study of the distribution of HTLV-I seropositivity in a total community.

The population of Trinidad is of African, Indian, European, Chinese, Lebanese and Syrian descent. The forbears of those of African origin arrived after 1776, coming either directly from West Africa or by way of neighbouring islands such as Grenada. People of Indian descent came from 1845 onwards, mostly from northern India. Smaller numbers of Chinese entered Trinidad after 1852.
Port-of-Spain lies on the coast of N.W. Trinidad and has a humid tropical climate. The survey was conducted in a defined area encompassing contiguous sectors of two suburbs of the city which we refer to as sectors A and B. Although in general the A-sector community is of lower socio-economic standing than sector $\mathrm{B}$, there is no appreciable difference between Africans and Indians in living standards within the A sector.

Sera were screened for HTLV-I with an enzyme-linked immunosorbent assay (ELISA) [33]. Samples positive with this test were examined with an ELISA modification of a previously described competitive assay [40]. Only subjects whose sera were positive to both assays were considered sero-positive for HTLV-I.

Details of this study are published elsewhere [25]. Several important facts emerged: 1. Individuals of Asian (Indian) descent were infected at a lower rate $(1.4 \%)$ than AfroCaribbean blacks $(7.0 \%)$. 2. As in Japan, sero-positivity rates were age and sex associated, the highest rates $(12.3 \%)$ being observed in females over 65 years of age. 3 . Black males living in the less-prosperous sector A were infected at a higher rate $(5.4 \%)$ than those living in sector B $(2.6 \%)$. 4. Seropositivity was significantly $(P<0.001)$ associated with poor-quality housing. 5 . Seropositivity was significantly $(P<0.025)$ associated with living distances of less than $30 \mathrm{~m}$ from open water courses.

We have suggested [25] that, when taken together, the household clustering of HTLV-I infection (documented in Japan), the increased risk to adult females, the association with poor-quality housing and proximity to insect breeding sites (i.e. open, stagnant water) implicate an insect vector of intensively domestic habit. One candidate would be the mosquito species Aedes aegypti, which is known to have limited dispersal from its breeding grounds [27], but other domestic insects including mites and ticks would also be candidates. Women might be more likely to be infected than their husbands by virtue of their spending more time in the house and therefore incurring a greater risk of exposure. In the Caribbean region, non-black ethnic groups might be infected only by co-habitation with people of African descent who probably provide the 
host reservoir for the virus, and this would need to be prolonged if infectivity were very low. This might then explain why Indians, though infected with HTLV-I, have a much lower sero-positivity rate in Trinidad than do inhabitants of African origin.

The increasing sero-positivity with age still requires an explanation. One possibility is that it reflects the requirement for continuous exposure to potential sources of virus coupled with inefficient transmission. Another possibility is that the age association is merely a mirror of historical events, with young people now being infected at a much lower rate due, for example, to improving living conditions. We have assumed that if blood-sucking insects are capable of transmitting HTLV-I this will be via the purely mechanical transfer of infected lymphocytes. At this stage, however, it remains possible, though perhaps less likely, that insects serve as a biological vector supporting viral replication, as happens, for example, with the Japanese encephalitis arbovirus [34]. This is currently being investigated.

Finally, it is important in this context to re-emphasise the similarity between HTLV-I and bovine leukaemia virus (BLV) with respect to viral structure and disease similarities [8, 39]. Although BLV in developed countries may commonly be transmitted iatrogenically, there may well be a role for haematophagous insects as mechanical vectors, especially in tropical regions. Experimental evidence for this has been produced [2, 9, 12]. BLV does not, however, spread readily within a herd of cows, and physical contact is almost certainly required [29]. This might again implicate an insect vector other than common mosquitoes.

It is of interest that BLV can be experimentally transferred by injecting a sero-negative cow with $100 \mu$ l of blood or around 1000-2000 lymphocytes from an infected cow, but that this value drops by 3 orders of magnitude if the donor cow has a BLV-associated lymphocytosis (A. Burny, this volume). The latter corresponds to the transfer of less than $0.1 \%$ of the volume of a mosquito blood feed which could easily be carried on the mouthparts. Perhaps HTLV-I is effectively transmitted only by blood-sucking insects that have had an interrupted meal on a sero-positive individual with some de- gree of lymphocytosis. This might then explain the apparent need for close familial contact over a prolonged period.

It is clear that HTLV-I has been transmitted by blood transfusion in Japan [16], and we do not contest that infection can be spread via breast feeding or sexual contact. Although several modes of transmission may be possible, we hypothesise that insect vectors play a more significant role than has hitherto been appreciated.

Acknowledgements. The work reported here was supported by the Leukaemia Research Fund of Great Britain and will be reported in detail elsewhere. Our collaborators in this work include Dr. N. Byam and Dr. G. Beckles (Port of Spain, Trinidad), Dr. R. Kirkwood, Dr. D.C. Carson, Dr. L. Chan, Dr. L. Kinlen, Dr. T. A. Lister, Ms. S. M. Pegram and Ms. S. Claydon. We thank Ms. G. Parkins and Mrs. J. Needham for typing the manuscript.

\section{References}

1. Bartholomew C, Charles W, Saxinger C, Blattner W, Robert-Guroff M, Raju C, Ratan P, Ince W, Quamina D, Basdeo-Maharaj K, Gallo RC (1985) Racial and other characteristics of human T-cell leukaemia/lymphoma (HTLV-I) and AIDS (HTLV-III) in Trinidad. Br Med J 290:1243-1246

2. Bech-Nielsen S, Piper CE, Ferrer JF (1978) Natural mode of transmission of the bovine leukemia virus: role of blood-sucking insects. Am J Vet Res 39:1089-1092

3. Biggar RJ, Gigase PL, Melbye M, Kestens L, Sarin PS, Bodner AJ, Demedts P, Stevens WJ, Paluku L, Delacollette C, Blattner WA (1985) Elisa HTLV retrovirus antibody reactivity associated with malaria and immune complexes in healthy Africans. Lancet II:520-523

4. Biggar RJ, Johnson BK, Oster C, Sarin PS, Ocheng D, Tukei $P$, Nsanze $H$, Alexander $S$, Bodner AJ, Siongo TA, Gallo RC, Blattner WA (1985) Regional variation in prevalence of antibody against human $\mathrm{T}$-lymphotropic virus types I and III in Kenya, East Africa. Int J Cancer 35:763-767

5. Biggar RJ, Saxinger C, Gardiner C, Collins WE, Levine PH, Clark JW, Nkrumah FK, Blattner WA (1984) Type-I HTLV antibody in urban and rural Ghana. Int $J$ Cancer 34:214-219

6. Blattner WA, Gibbs WN, Saxinger C, Robert-Guroff M, Clark J, Lofters W, Han- 
chard B, Campbell M, Gallo RC (1983) Human T-cell leukaemia/lymphoma virus-associated lympho-reticular neoplasia in $\mathrm{Ja}$ maica. Lancet II:61-64

7. Blattner WA, Kalyanaraman VS, RobertGuroff M, Lister TA, Galton DAG, Sarin PS, Crawford MH, Catovsky D, Greaves M, Gallo RC (1982) The human type-C retrovirus, HTLV, in Blacks from the Caribbean region, and relationship to adult T-cell leukaemia/lymphoma. Int J Cancer 30:257-264

8. Burny A, Bruck C, Couez D, Deschamps J, Ghysdael J, Kettmann R, Mammerick M, Marbaix G, Portetelle D (1984) Enzootic bovine leukemia: its relevance as a model system for humen T-cell leukemia. In: Gallo RC, Essex ME, Gross L (eds) Human T-cell leukemia/lymphoma virus. Cold Spring Harbor Laboratory, New York, pp 17-24

9. Buxton BA, Schultz RD, Collins WE (1982) Role of insects in the transmission of bovine leukosis virus. Potential for transmission by mosquitoes. Am J Vet Res 43:1458-1459

10. Catovsky D, Greaves MF, Rose M, Galton DAG, Goolden AWG, McCluskey DR, White JM, Lampert I, Bourikas G, Ireland R, Brownell AI, Bridges JM, Blattner WA, Gallo RC (1982) Adult T-cell lymphoma-leukaemia in Blacks from the West Indies. Lancet I:639643

11. De The G, Gessain A, Gazzolo L, RobertGuroff M, Najberg G, Calender A, M'Pnagi P, Brubaker G, Benslimane A, Fabry J, Strobel M, Robin Y, Fortune R (1986) Comparative seroepidemiology of HTLV-I and HTLV-III in French West Indies and some African countries. Cancer Res (in press)

12. Fischer RG, Leucke DH, Rehacek J (1973) Friend leukaemia virus (FLV) activity in certain arthropods. III. Transmission studies. Neoplasma 20:255-260

13. Gallo RC, Sliski A, Wong-Staal F (1983) Origin of human $\mathrm{T}$-cell leukaemia-lymphoma virus. Lancet II:962-963

14. Gessain A, Jouannelle A, Escarmant P, Calender A, Schaffar-Deshayes L, The G de (1984) HTLV antibodies in patients with nonHodgkin lymphomas in Martinique. Lancet I:1183

15. Greaves MF, Verbi W, Tilley R, Lister TA, Habeshaw J, Guo H-G, Trainor CD, RobertGuroff M, Blattner W, Reitz M, Gallo RC (1984) Human T-cell leukaemia virus (HTLV) in the United Kingdom. Int J Cancer 33:795-806

16. Hino S, Kawamichi T, Funakoshi M, Kanamura M, Kitamura T, Miyamoto T (1984) Transfusion-mediated spread of the human $\mathrm{T}$-cell leukaemia virus in chronic hemodialy- sis patients in a heavily endemic area, Nagasaki. Gann 75:1070-1075

17. Hino $S$, Yamaguchi $K$, Katamine $S$, Sugiyama $\mathrm{H}$, Amagasaki $\mathrm{T}$, Kinoshita $\mathrm{K}$, Yoshida Y, Doi H, Tsuji Y, Miyamoto T (1985) Mother-to-child transmission of human T-cell leukemia virus type I. Gann 76:474-480

18. Hinuma $\mathrm{T}$, Komoda $\mathrm{H}$, Chosa $\mathrm{T}$, Kondo $\mathrm{T}$, Kohakura M, Takenaka T, Kikuchi M, Ichimaru M, Yunoki K, Sato I, Matsuo R, Takiuchi Y, Uchino H, Hanaoka M (1982) Antibodies to adult T-cell leukaemia-virus-associated antigen (ATLA) in sera from patients with ATL and controls in Japan: a nationwide sero-epidemiological study. Int J Cancer 29:631-635

19. Hinuma $Y$, Nagata $K$, Nakai $M$, Matsumoto T, Kinoshita K, Shirakawa S, Miyoshi I (1981) Adult T-cell leukemia: antigen in an ATL cell line and detection of antibodies to the antigen in human sera. Proc Natl Acad Sci USA 78:6476-6480

20. Hunsmann G, Schneider J, Schmitt J, Yamamoto N (1983) Detection of serum antibodies to adult $\mathrm{T}$-cell leukaemia virus in non-human primates and in people from Africa. Int $J$ Cancer 32:329-332

21. Komuro A, Hayami M, Fujii H, Miyahara S, Hirayama M (1983) Vertical transmission of adult T-cell leukaemia virus. Lancet I:240

22. Manzari V, Gradilone A, Barillari G, Zani M, Collalti E, Pandolfi F, de Rossi G, Liso V, Babbo P, Robert-Guroff M, Frati L (1985) HTLV-I is endemic in southern Italy: detection of the first infection cluster in a white population. Int J Cancer 36:557-559

23. Merino F, Robert-Guroff M, Clark J, Biondo-Bracho M, Blattner WA, Gallo RC (1984) Natural antibodies to human T-cell leukaemia/lymphoma virus in healthy Venezuelan populations. Int J Cancer 34:501-506

24. Miller GJ, Beckles GLA, Byam NTA, Price SGL, Carson DC, Kirkwood BR, Baker IA, Bainton D (1984) Serum lipoprotein concentrations in relation to ethnic composition and urbanization in men and women of Trinidad, West Indies. Int J Epidemiol 13:413-421

25. Miller GJ, Pegram SM, Kirkwood BR, Beckles GLA, Byam NTA, Clayden SA, Kinlen LJ, Chan LC, Carson DC, Greaves MF (1986) Ethnic composition, age, sex, and the location and standard of housing as determinants of HTLV-I infection in an urban Trinidadian community. Int J Cancer 38:801808

26. Minwor M, Sugano $H$, Sugimura $T$, Weiss RA (eds) (1985) Retroviruses in human lymphoma/leukaemia. Japan Scientific Soc. Press, Tokyo 
27. Morlan HB, Hayes RO (1958) Urban dispersal and activity of Aedes aegypti. Mosquito News 18:137-144

28. Nakano S, Ando $Y$, Ichijo $M$, Moriyama I, Saito S, Sugamura K, Hinuma Y (1984) Search for possible routes of vertical and horizontal transmission of adult T-cell leukaemia virus. Gann 75:1044-1045

29. Piper CE, Abt DA, Ferrer JF, Marshak RR (1975) Seroepidemiological evidence of the horizontal transmission of the bovine C-type virus. Cancer Res 35:2714

30. Poiesz BJ, Ruscetti FW, Gazdar AF, Bunn A, Minna JD, Gallo RC (1980) Detection and isolation of type-C retrovirus particles from fresh and cultured lymphocytes of a patient with cutaneous T cell lymphoma. Proc Natl Acad Sci USA 77:7415-7419

31. Reitz MS, Poiesz BJ, Ruscetti FW, Gallo RC (1981) Characterization and distribution of nucleic acid sequences of a novel type-C retrovirus isolated from neoplastic human T-lymphocytes. Proc Natl Acad Sci USA 78:18871891

32. Robert-Guroff M, Clark J, Lanier AP, Beckman G, Melbye M, Ebbesen P, Blattner WA, Gallo RC (1985) Prevalence of HTLV-I in arctic regions. Int J Cancer 36:651-655

33. Saxinger C, Gallo RC (1983) Application of an indirect ELISA microtest to the detection and surveillance of human T-cell leukemia/ lymphoma virus (HTLV). Lab Invest 49:371377

34. Shiraki H (1970) Japanese encephalitis. In: Debre R, Celers J (eds) Clinical virology. The evaluation and management of human viral infections, chap 11. W.B. Saunders, Philadelphia, pp 155-175

35. Tajima K, Fujita K, Tsukidate S, Oda T, Tominaga S, Suchi T, Hinuma Y (1983) Seroepidemiological studies on the effects of filarial parasites in infestation of adult T-cell leukaemia virus in the Goto Islands, Japan. Gann 74:188-191

36. Tajima K, Tominaga S, Suchi T, Kawagoe T, Komoda H, Hinuma Y, Oda T, Fujita K (1982) Epidemiological analysis of the distribution of antibody to adult T-cell leukaemia-virus-associated antigen: possible horizontal transmission of adult T-cell leukaemia virus. Gann 73:893-901

37. Watanabe T, Seiki M, Yoshida M (1984) HTLV type I (US isolate) and ATLV (Japanese isolate) are the same species of human retrovirus. Virology 133:238-241

38. Williams CK, Saxinger WC, Alabi GO, Junaid TA, Blayney DW, Greaves MF, Gallo RC, Blattner WA (1984) HTLV-associated lymphoproliferative disease: report of 2 cases in Nigeria. Br Med J 288:1495-1496

39. Wong-Staal F, Gallo RC (1985) Human Tlymphotropic retroviruses. Nature 317:395403

40. Tedder RD, Shanson DC, Jeffries DJ, Cheingsong-Popov R, Clapham P, Dalgleish A, Nagy K, Weiss RA (1984) Low prevalence in the UK of HTLV-I and HTLV-II infection in subjects with AIDS, with extended lymphadenopathy, and at risk of AIDS. Lancet II: $125-128$ 